\title{
Feminist anger and feminist respair
}

\author{
Jilly Boyce Kay and Sarah Banet-Weiser
}

University of Leicester; The London School of Economics and Political Science

\section{Introduction: the age of anger}

How bad things have become. Or perhaps it is more accurate to say: how bad things have always been. But it is only now that some people with particular kinds of class and race privilege are beginning to grasp just how awful things are: how very deeply racism and misogyny are entrenched in our culture; how devastating neoliberalism has been to social bonds and human lives; how impending ecological disaster is increasingly not a possibility but a sure-fire certainty. We seem to be in a moment of intense despair, hopelessness and powerlessness; politics and public institutions as we know them are unravelling --- and not in a good way. We are living in what Pankaj Mishra (2017) calls the "age of anger", in which modernity has singularly failed to live up to its promises of democracy, equality and freedom, and has thus given rise to the spread of a deep ressentiment that manifests as the normalisation of nationalisms, racisms, and misogynies.

Anger, we might say, has filled the space where the hope of modernity used to be --- a hope that turned out to be profoundly (and humiliatingly) misplaced. As Mishra shows, this anger is resentful, festering, and deeply reactive. It is most often misdirected --- at women, LGBTQ people, migrants, refugees, and people of colour. It provides no creative vision or hope for humanity, but nonetheless it thrives and grows: in its impotency, the rage is destructive. The popular misogyny that Sarah Banet-Weiser (2018) identifies seems to have deep affective and political affinities with the festering moods of this anger. In this context of 
intensifying and extensifying hate, whose terrifying power seems ineluctable and uncontainable, it is perhaps no wonder how, for those of us who research and think and live as feminists, a sense of deep despair seems to prevail.

And yet, at the same time, we are witnessing an extraordinary new visibility of women's anger --- we might even say feminist anger --- in public discourse and popular culture; most strikingly, in the wake of the \#MeToo movement (Rebecca Traister 2018). Whereas popular feminism has hitherto been characterised by a clear repudiation of anger (Rosalind Gill 2016; Sarah Banet-Weiser 2018), might we be in the midst of a new shift, in

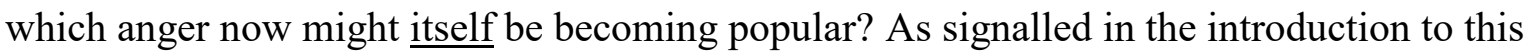
Commentary and Criticism section, we might ask: has rage become all the rage? Mainstream media culture seems to be newly awash with the public voicing of women's rage and trauma, in a way that seems and feels unprecedented (Jilly Boyce Kay forthcoming). What might we make of this new visibility of women's anger in media culture? As Banet-Weiser (2018) shows, to prosper in an economy of visibility has only very limited value for feminism, because this is precisely where it tends to remain --- at the level of visibility. While white masculine anger becomes institutionalised, empowered and weaponised, might this female rage --- like popular feminism --- fail to move beyond the realm of visibility?

Mishra does not account for women's rage in the "age of anger"; rather, he conflates this with masculine ressentiment. Indeed, there seems to be a wider tendency for the media to neglect women's anger in discussions of contemporary politics and populist anger (consider the journalistic clammering to understand the concerns and resentments of white men who voted for Trump, but the almost total lack of mainstream media interest in why so many black women voted for Clinton; or the ways in which the figure of the "left behind" voter in the Brexit referendum is so frequently imagined as a white working-class man). Women's rage cannot be understood in precisely the same way that Mishra understands anger --- that is, 
as the ugly but inevitable product of modernity's failures to deliver on its promises of autonomy and equality ---- because women were simply never made those same promises. If the anger that Mishra identifies as characteristic of our contemporary political culture is based on the humiliation and resentment of (white) men --- and as something corrosive, sabotaging, and malignant --- then how might we conceive of and cultivate an anger that is legitimate, creative, animating and, most of all feminist? Of course, this is not to suggest that all anger that is experienced, embodied and expressed by all women is in opposition to the ressentiment identified by Mishra, or that it is inevitably virtuous or progressive --- we need only think of Anne Coulter, or Marine Le Pen, or the fact that so many white women voted for Trump, to understand that regressive, hateful rage on the one hand, and productive anger on the other, do not align uncomplicatedly with gender binaries. The task, then, is to identify more precisely which angers we might wish to nurture and develop.

\section{Public anger and affective injustice}

In most western philosophical traditions, anger is seen as morally problematic and politically counterproductive, as Amia Srinivasan (2016) argues. Because it traps its agents in an inward-looking, retributive and sometimes narcissistic frame --- blocking the possibility of a more just future that is based on civic love and generosity --- it is most often construed as fundamentally antithetical to political justice (Martha Nussbaum 2016). On the other hand, there is a compelling tradition from black feminist thought which understands anger as a productive resource, most famously as expressed by Audre Lorde:

Every woman has a well-stocked arsenal of anger potentially useful against those oppressions, personal and institutional, which brought that anger into being. Focused with precision it can become a powerful source of energy serving progress and change. And when I speak of 
change, I do not mean a simple switch of positions or a temporary lessening of tensions, nor the ability to smile or feel good. I am speaking of a basic and radical alteration in all those assumptions underlining our lives (Audre Lorde 1997 [1981], 280)

Brittney Cooper (2018) has also written recently on the eloquence of black feminist rage she draws heavily on Lorde, whilst also acknowledging that anger is not always "focussed with precision". She suggests that anger can be "messy", particularly for black girls and women who do not have the same kinds of access to the "process" and reflection necessary for focussed anger.

Amia Srinivasan (2018) has written an excellent and nuanced defence of anger, against Martha Nussbaum's Aristotelian notion of anger as counterproductive. Srinivasan, following Lorde, notes how anger, as well as being a source of energy, can also be clarifying; it is "a means by which women can come to better see their oppression" $(2018,4)$. Nonetheless, she notes that even when anger is apt --- when it is a fully justified and appropriate response to injustice --- getting angry is a risky endeavour for those who are "already stereotyped as rageful, violent, or shrill" (14). Of course, those whose anger is most likely to disqualify them from the racist, sexist terms of the "civilised" public sphere are women --- and most especially black women. Such victims of injustice, Srinivasan argues, are too often forced to choose between publicly expressing their justified rage, and modulating or suppressing it in order to satisfy the norms of the public sphere. Srinivasan terms this unequal access to public rage and the painful normative conflicts that it generates affective injustice.

We only need to think of some recent displays of anger to see gendered affective injustice at work in media and political culture. The \#MeToo movement was in many ways 
about female anger: anger at widespread and normalized sexual harassment in all industries; anger at so few harassers being held accountable for their violent actions; anger at not being believed for so long; anger at having to relive trauma again and again, often on social media, in order to be finally heard. Yet, during the year in which \#MeToo stories circulated on media platforms, other stories competed for dominance and visibility: stories of male anger, of men claiming the mantle of victimhood, lashing out at women (and feminists in particular) as the perpetrators of their injuries. Because this assumed injury to men --- often white men in positions of power --- was so unusual to them, given their privileged lives, this male anger was often framed by the mainstream media as somehow more authentic than female anger. Indeed, this is a clear example of affective injustice, where angry women have been historically cast as hysterical and irrational, and men's anger has been seen as an appropriately masculine response. We need only to reflect on the US Supreme Court (then) nominee Brett Kavanaugh's Senate Hearings, where he was accused of sexually assaulting Christine Blasey Ford in high school, to understand some of the dynamics of affective injustice.

During the hearings, it seemed so painfully clear that Blasey Ford understood extremely well the affective terms upon which she would be understood as "credible" and "legitimate". She presented her case powerfully and quietly, testifying to the long-lasting trauma of sexual assault and humiliation ("indelible in the hippocampus is the laughter."). Because women are so often not believed, especially if they are angry, Blasey Ford appeared to work very hard to ensure that her communicative mode was free of any angry inflection.

Kavanaugh, on the other hand, took the opportunity to display a full range of emotions, from rage to petulant whining. He was disrespectful of his questioners, he was self-absorbed, he was irrational. Yet his anger, at least according to some, came from an authentic place: how dare someone accuse him of this horrible act, and as Republican Senator Lindsay Graham 
shouted, "destroy this guy's life"? Kate Manne (2018) has written astutely of the ways that the support shown for Kavanaugh was a classic case of "himpathy": that is, "the inappropriate and disproportionate sympathy powerful men often enjoy in cases of sexual assault, intimate partner violence, homicide and other misogynistic behavior' (see also Kate Manne 2018a). We might say that himpathy plays a powerful role in affective injustice; it permits and legitimises the public outrage of male perpetrators, but disallows the justified anger of victims and survivors.

For those of us who were riveted to the television during the Anita Hill/Clarence Thomas hearings almost 30 years before, which were also about a claim of sexual harassment, we couldn't help but notice the deeply troubling similarities. Anita Hill was calm and rational in her accusations, like Blasey Ford. Yet Hill had to fight against racist histories which positioned Black women's anger as even more hysterical, irrational, and untrustworthy (Jennifer Asenas and Sierra Abram 2018). Thomas, on the other hand, in his anger, called on some of those same racist histories to position himself as the victim. Hill, as a Black woman, had no available narrative for the telling, as Kimberle Crenshaw (1992) has so powerfully argued.

This affective injustice has a deep history. When Thomas was confirmed as a US Supreme Court justice, it was a moment when sexual harassment was hardly in the national imagination in the US --- at least not as something for which men should be held accountable. But Kavanaugh was confirmed in the context of the \#MeToo movement; a movement which has at least offered widespread public awareness that sexual harassment is a structural problem. What should we make of this? The sense of overwhelming despair that so many of us felt following Kavanaugh's confirmation was surely connected to the realisation that the anger of \#MeToo had not been enough; that what had felt like the unprecedented power of women's rage could not, in the end, batter down the doors of white male entitlement; that 
misogyny, after all those deeply painful and traumatic disclosures --- after everything --- had still won. Even if women did everything "right", and had played by the affective rules, as Blasey Ford had done, we would still lose, because the rules of the game are fundamentally rigged against us. Expressing anger had not worked; modulating anger had not worked; affective injustice, it seems, has us in trapped in a double-bind and it is difficult to see how we might ever get out of it. When anger is mobilised for feminist ends and still appears incapable of cracking the edifice of patriarchal and misogynistic power, it leaves a way for deep despair to set in.

\section{From despair to respair}

Hope and despair are most often understood as one another's opposite; indeed, dictionary definitions position them as antonyms, as in the Oxford Dictionary which has despair as: "The complete loss or absence of hope". It is worth here considering that hope and despair might not be as mutually exclusive as might commonly be supposed. Terry Eagleton (2015) distinguishes between hope on the one hand, and optimism on the other; to have an optimistic disposition is actually deeply conservative --- it assumes that things will get better without the need for any genuine investment or hard work. Hope, by contrast, requires a confrontation with the bitterest truths --- a recognition of just how bad things are. In this sense, then, it is not so antithetical to despair. So, while optimism functions as a block to transformative change, "bleakness, by contrast, can be a radical posture. Only if you view your situation as critical do you recognise the need to transform it" (Eagleton 2015, chapter 1). Despair can --seemingly paradoxically --- be productive of hope.

Lorde and Srinivasan have pointed us towards the importance of anger's role in clarifying the nature and cause of injustice. Might despair, like anger, have a similar 
clarificatory role? If we are living in a moment when the depth, reach and power of misogyny have become horrifyingly clear, then despair need not point towards a political defeatism, but rather to a politically necessary illumination. After all, if we are truly to struggle against patriarchy and neoliberal capitalism, it is of primary importance that we confront the scale of that which we are faced with. Sara Ahmed argues that "revolutionary forms of political consciousness involve heightening our awareness of what there is to be unhappy about" $(2010,592)$. Despair need not be a withdrawal from or a giving up on the political, then, but a kind of illuminating, galvanising bleakness.

There is a $15^{\text {th }}$ century word that has long fallen out of use but which we think is highly apt for the current moment, and which captures this complex relationship between hope and despair: respair means fresh hope; a recovery from despair. It speaks to the inextricability of hope and despair: it is not only that one might follow after the other, but also that they often simultaneously co-exist, are entangled and mutually dependent. The presence of despair does not equate to the absence of hope: and indeed, perhaps the presence of the former is a precondition for the meaningful existence of the latter. It is precisely the bland, empty optimism and the denial of anger and pain that render neoliberal and popular feminisms so devoid of any meaningful political power. It is only by embracing anger and despair --- and recognising them as legitimate aspects of our politics --- that we can hope for genuine, transformative change.

In this sense, respair is in opposition to what Lauren Berlant (2011) has astutely called “cruel optimism.” For women, Berlant argues, investing in a utopic normativity (including investing in the state) is decidedly against women's best interest, it is a "love affair with conventionality" (Berlant 2008, 2). Investing in a politics of anger that insist that women must be quiet and "rational" in order to be credible is cruel optimism. While understandable, refusing to express rage at systemic injustice because of the way women's rage is widely 
understood and interpreted, will work only to retrench patriarchal relations, not disrupt them. When, in a himpathetic culture, victimhood is appropriated not by those who have historically suffered but by those in positions of patriarchal power, such as with Kavanaugh, this maintains a hegemonic gender order. When rage is disallowed from those who suffer and offered as a platform for the privileged, it establishes a symbolic redistribution of gender asymmetry. At the same time, a feminist politics of anger also needs to account for the double-bind of affective injustice; a recognition that the public expression of rage comes with its own treacherous potential for backlash. Rage is full of feminist possibility, but also of risk --- and these risks of rage are not evenly shared by all women.

Respair points to the inextricability of hope and despair that is entailed in any feminist endeavour. Misogyny, racism, homophobia, transphobia, abuse, humiliation, and exploitation are deeply endemic and everyday facts of life; these deep harms cause trauma, pain and despair. Hope is of course necessary to help repair these harms, but respair allows us to cultivate a hope that lets us keep sight of the fact that we are vulnerable, and damaged, and that we have been hurt in ways that perhaps we might never get better from. The despair of respair, after all, is what has given us the bleak illumination we need to allow for any meaningful political work to take place. Things are worse than we thought; the task is so much greater than we knew. This can be mobilising rather than immobilising, if we try to rethink despair as something to be worked with rather than against. Respair is a hope that comes out of brokenness, but which does not mandate optimism or insist on happiness as an antidote or cure. Respair always has room for "affect aliens" (Ahmed 2011) who are otherwise made to feel estranged from emotional regimes of optimism and happiness.

The despair of respair is therefore not a withdrawal or an exit from the political. It is, to use Donna Haraway's (2016) term, about "staying with the trouble". As Sarah Sharma (2017) has shown, we increasingly now see a growing desire for exit, for quitting, for saying 
"screw this", and for escape. The penchant for exit, she suggests, falls along patriarchal and masculinist lines --- she terms this the "sEXIT" --- and argues that such a desire is not compatible with a feminist politics, which must always centre contingency and care.

Respair is a hope that recognises the need for care, for mutual support, for the neverending need for collectivity. This differentiates it from an individual rage; respair insists on what Silvia Federici (2018) calls a "collective subject." We might think of respair as the feminist rejoinder to the sEXIT; respair is about staying with the trouble, sticking with the mess, and committing to the hard work of repair collectively, not individually. Respair recognises the intrinsic vulnerability and interdependency of humans; it recognises that we need to carry each other, in order to not shoulder the harms of affective injustice alone. Respair might also help us to keep hoping even when all the odds seem stacked against us --because it is only by seeing those odds and just how big they are that we will have any chance of beating them.

\section{References}

Ahmed, Sara (2010) 'Killing Joy: Feminism and the History of Happiness' in Signs, 35 (3) $571-594$

Ahmed, Sara (2011) The Promise of Happiness. Durham: Duke University Press. Asenas, Jennifer \& Sierra Abram (2018) Flattening the past: how news media undermine the political potential of Anita Hill's story, Feminist Media Studies, 18:3, 497-499

Banet-Weiser, Sarah (2018) Empowered: Popular Feminism and Popular Misogyny. Durham: Duke University Press.

Beard, Mary (2015) 'The Public Voice of Women', Women's History Review, 24(5) 809-818 
Berlant, Lauren (2008) The Female Complaint: The Unfinished Business of Sentimentality in American Culture. Durham: Duke University Press

Berlant, Lauren (2011) Cruel Optimism. Durham: Duke University Press

Cooper, Brittney (2018) Eloquent Rage: A Black Feminist Discovers Her Superpower. New York: St Martins Press.

Crenshaw, Kimberlé. 1992. Whose Story Is It, Anyway? Feminist and Antiracist appropriations of Anita Hill. In Race-ing Justice, En-Gendering Power: Essays on Anita Hill, Clarence Thomas, and the Construction of Social Reality, edited by Toni Morrison, 402-440. New York: Pantheon Books.

Eagleton, Terry. 2015. Hope without Optimism. London: Yale University Press.

Federici, Silvia. 2018. Re-enchanting the World: Feminism and the Politics of the Commons. Toronto: Between the Lines.

Kay, Jilly B. (forthcoming, 2019) 'Celebritised anger: theorising women’s rage, voice and affective injustice through Hannah Gadsby's Nanette' in Gender and Australian Celebrity

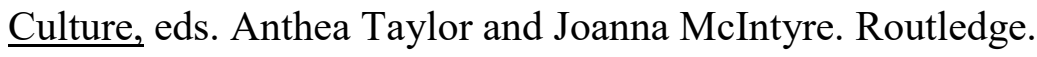

Lorde, Audre (1997 [1981]) 'The Uses of Anger' in Women's Studies Quarterly, 25 (1/2), $278-285$

Manne, Kate (2018) 'Brett Kavanaugh and America's "Himpathy” Reckoning', New York Times. https://www.nytimes.com/2018/09/26/opinion/brett-kavanaugh-hearinghimpathy.html

Manne, Kate (2018a) Down Girl: the Logic of Misogyny. Oxford: Oxford University Press. Mishra, Pankaj (2017) The Age of Anger: A History of the Present. London: Penguin. 
Nussbaum, Martha C. (2016) Anger and Forgiveness: Resentment, Generosity, and Justice.

Oxford: Oxford University Press.

Sharma, Sarah (2017) 'Exit and the extensions of man' in Transmediale: Art and Digiculture. https://transmediale.de/content/exit-and-the-extensions-of-man

Srinivasan, Amia (2016) 'Would politics be better off without anger?', The Nation, https://www.thenation.com/article/a-righteous-fury/

Srinivasan, Amia (2018) 'The Aptness of Anger' The Journal of Political Philosophy: 26 (2), $123-144$

Traister, Rebecca (2018) Good and Mad: the Revolutionary Power of Women's Anger.

London: Simon \& Schuster 